\title{
Global civil society must promote linguistic rights for China's Indigenous peoples
}

Edition 6, 2021

Dr Gerald Roche

DOI: 10.37839/MAR2652-550X6.21

Approximately 300 languages are spoken in China, and about half are being eliminated. A major factor driving this crisis is China's successful isolation of its citizens from transnational civil society that supports Indigenous languages in forums such as the United Nations.

Two things enable China to get away with this: the country denies its colonial history and refuses to acknowledge that it has Indigenous people.

The United Nations Permanent Forum on Indigenous Issues has stated that of the world's 6,700 languages, between 50 percent and 95 five percent 'will become extinct by 2100'. Indigenous languages constitute the vast majority of these 'threatened' languages. This situation is 'the direct result of colonialism and colonial practices,' and addressing it has become 'the most critical issue' faced by Indigenous people around the world today.

In response to this situation, a flurry of activities was organised in 2019, which was declared the International Year of Indigenous Languages, and which led to the launch of an International Decade of Indigenous Languages from 2022 to 2032. Judging by the activities undertaken in 2019, building transnational civil society in support of Indigenous languages will continue to be a major priority of those involved. 
However, looking back at the activities held in the Year of Indigenous Languages also suggests that the civil society that emerges across this decade will not include any people or organisations from China. The official website of the International Year of Indigenous Languages lists only three formal events in China, and one of these was organised by the Philippine Embassy in Beijing. The quietude of China in this area in 2019 demonstrates its refusal to recognise its Indigenous peoples and their languages.

\section{Denying indigeneity}

China does not allow its citizens to identify as Indigenous people. Instead, the Partystate divides the population into minzu, a term which is variously translated as nationality or ethnicity. Some 92 percent of the population belong to the country's majority minzu, the Han. The remaining population is divided between 55 minority $\operatorname{minzu.}$

Minority minzu people have been incorporated into China's territory and political system through a history of colonial expansion. The people of Xinjiang, including the Uyghurs, were violently incorporated into Qing China (1644-1911) during the mideighteenth century, giving rise to what one historian has called the first modern genocide: the destruction of the Dzungar people. Various parts of Tibet were incorporated into Qing China across the eighteenth century at different times (though interactions between Tibetans and Han Chinese predate this, including the Tibetan seizure of the Tang Dynasty capital of Chang'an, today's Xi'an). When the Chinese Communist Party came to power in 1949, it took over the vast majority of these colonised territories and people.

Despite this history of colonialism, we cannot simply consider 'minority minzu' and 'Indigenous people' to be equivalent terms. Part of the reason why minzu is so difficult to translate into English is its specificity to the Chinese context. The concept is a complex blend of nineteenth century racism, European romantic nationalism, 
and Marxist evolutionary theory, filtered through the thought of Joseph Stalin and combined with Han Chinese concepts of descent and kinship.

Understanding the Marxist evolutionary foundations of minzu is particularly important for how we think about minzu and their relation to Indigenous people and languages. Each minzu in China is an amalgamation of distinct peoples, languages, and identities. These distinct groups have been bundled together by the state under the assumption that they share a common history of descent: that each was, in the past, a single group. The Party's aim in lumping these different, but historicallyrelated peoples together, is to reverse the fracturing tide of history. The state aims to assimilate peoples and languages into minzu groups, which will all ultimately be assimilated into the Han majority. Minzu, therefore, are not categories that recognise and respect diversity, but rather aim to conceal and destroy it.

If China has Indigenous peoples, then, they would be the groups which have been erased in the process of creating minzu. We can see the scale of destruction involved in this process of erasure by looking at the distinction between the number of minzu, 56 , and the number of languages-perhaps as high as 300. Although China's constitution claims to guarantee the freedom and equality of all languages, this only applies to the recognised languages of minzu, whereas all other languages are defined as dialects, which are not considered eligible for the same freedom and equality as languages. The people who speak and sign these languages are thus denied the right to have rights. Although they can use their languages in their private lives, these languages cannot be used in any public institutions, such as school and media. Nor does the state support efforts to develop these languages. 


\section{MELBOURNE ASIA REVIEW}

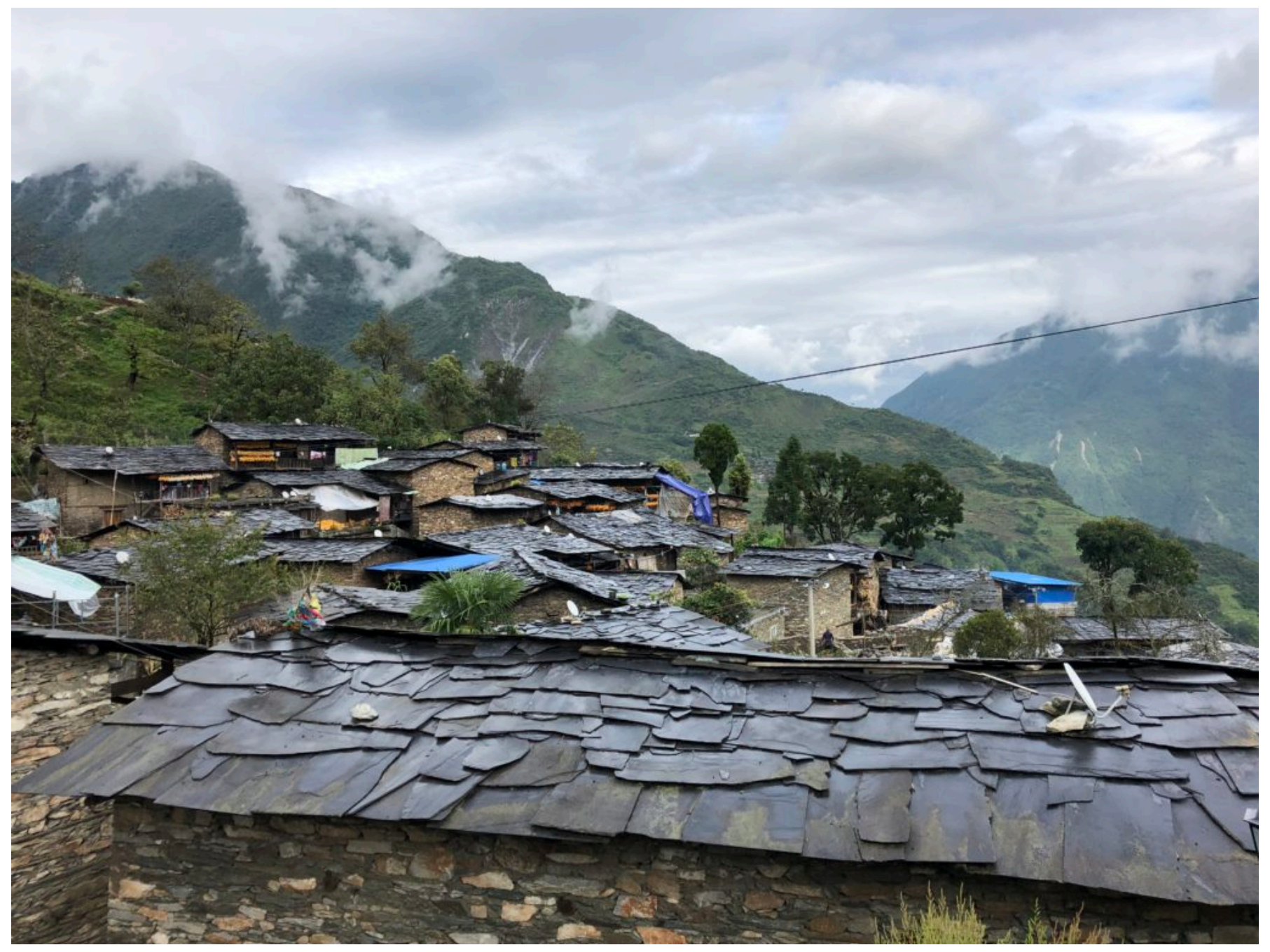

Taiwan demonstrates this system in action. China claims Taiwan as a 'renegade province,' and only recognises a single minority minzu there: the Gaoshan people. Meanwhile, the Taiwanese government uses a process of self-identification that enables Indigenous groups to nominate themselves. So whereas the Chinese Partystate would only recognise a single Gaoshan language, the Taiwanese government recognises 16 distinct languages, which are protected by the Indigenous Languages Development Act (2017). 


\section{Denying history}

Despite the history of colonialism described above, China denies the existence of its Indigenous people because it denies having ever engaged in colonialism.

Their approach to this issue was explicitly outlined during a 1995 UN working group session where a draft of the United Nations Declaration on the Rights of Indigenous People was discussed. During this session, the Chinese delegate justified their approach to this issue in three steps:

- Following the text of a UN fact sheet, the Chinese delegate defines Indigenous people as anyone who lived in a place prior to settlement and colonisation by outsiders.

- The Chinese government then states that, 'the question of indigenous peoples is the product of European countries' recent pursuit of colonial policies in other parts of the world.'

- If Indigenous people exist only in relation to European colonialism, it then follows that 'there is no indigenous peoples' question in China'; instead, 'the various nationalities in China have all lived for aeons on Chinese territory.

The logic that enables China to deny the existence of its Indigenous people asserts that colonialism is essentially something that Europeans did to the rest of the world. China is not alone in asserting this. In fact, this idea is supported by principles enshrined by the UN itself, in the form of what is called the 'blue water principle', whereby colonialism came to be effectively defined as an invading power having crossed an ocean.

This means that, when China claims they have no Indigenous people, they're technically correct. China has no Indigenous people according to this definition simply because it conquered territories that were not 'geographically separate' from Beijing. The invasion of Xinjiang and Tibet was therefore not colonialism, and without colonialism, there are no Indigenous people. This logic legitimises the Party- 
state's decision to abstain from participating in events such as the International Year and Decade of Indigenous Languages. And, ironically, it has also made China a vociferous supporter of Indigenous rights in the UN. For example, they were an early signatory to the United Nations Declaration on the Rights of Indigenous Peoples because they could confidently claim that it did not apply to them.

\section{Abandoning languages}

What does all this mean for China's unrecognised languages?

The languages of recognised minzu, like Tibetan, Uyghur, and Mongolian, are severely repressed. Although the state makes tokenistic gestures such as including 'minority' scripts on the currency, it has not provided the conditions to ensure that these languages continue to be successfully passed from one generation to the next.

The plight of these languages receives intense international attention through the media and civil society organisations. For example, in 2020, major media outlets around the world covered protests in Inner Mongolia, during which at least eight people took their own lives, after new restrictions were placed on the use of Mongolian in schools. Global civil society organisations such as PEN America, Human Rights Watch, and Amnesty International helped collect information about the situation and convey it to global audiences.

The plight of the Tibetan language also receives significant attention from global civil society. Human Rights Watch, for example, produces occasional reports dedicated to the topic, most recently in 2020. Both Amnesty International and PEN America have actively campaigned for the preservation of the Tibetan language, most recently in support of Tibetan language rights campaigner Tashi Wangchuk. A global network of civil society organisations funds and promotes the protection of the Tibetan language, helping to sustain pressure on China to ensure rights for the language and its speakers. 
However, in China, Tibetans also speak and sign about 30 languages in addition to Tibetan. The Party-state refuses to recognise that these languages exist. These languages are excluded from all public institutions, such as schooling and media. One domain where this exclusion is particularly harmful is public healthcare. Speakers and signers of Tibet's unrecognised languages cannot access any healthcare services in these languages-instead, they must rely on either Tibetan or Mandarin.

The harms of this situation became apparent during the COVID-19 pandemic. After the virus began spreading from Wuhan, translation into recognized minzu languages began, including Tibetan and Mongolian. However, no formal translation was undertaken for Tibetans who speak or sign unrecognised languages. Instead, communities had to mobilise to translate public health information themselves, without government support or oversight. This was particularly significant because the epicentre of the COVID-19 epidemic in Tibet was a region dominated by an unrecognised language. The state's refusal to recognise and support these languages therefore had potentially life-threatening consequences for the quarter of a million Tibetans who use them.

And yet, none of the global civil society organisations mentioned so far-PEN America, Amnesty International, or Human Rights Watch-have ever aimed to raise awareness about or support these languages. Instead, they consistently only refer to a single Tibetan language: the same one that the Party-state recognises. These communities are thus abandoned by the state and ignored by segments of global civil society that advocate for language rights in Tibet, and China more broadly.

\section{'Nothing for us without us'}

In launching plans for the International Decade of Indigenous Languages, the organisers declared that the theme of the decade would be, 'Nothing for us without us.' This motto emphasises the importance of participation by and consultation with 
Indigenous people in planning initiatives for Indigenous languages.

However, without a basic protection of the capacity to identify as Indigenous, there is no 'us' in China: no processes to be consulted about or to participate in, and nobody to consult or participate. Instead of providing a platform that empowers and protects the rights of the vulnerable, the UN is primarily used by China as a convenient authorisation of a vast project of historical denialism that enables the Party-state to continue human rights abuses against the country's most vulnerable linguistic communities. Meanwhile, global civil society has also failed to raise awareness about and promote the cause of the most vulnerable linguistic communities in Tibet.

The International Decade for Indigenous Languages offers an opportunity to address this failure. It is imperative that global civil society questions why China is granted the impunity to refuse Indigenous status to its citizens. It is also essential to lobby for a situation where Tibetans and others who speak and sign unrecognised languages are able to choose freely whether or not they wish to identify their communities and languages as Indigenous, and thus lay claim to the possibilities that will arise in the coming decade of awareness-raising and the building of transnational civil society in support of Indigenous languages.

As the International Decade of Indigenous Languages approaches, civil society organisations like PEN, Human Rights Watch, and Amnesty International should draw attention to the broader plight of China's unrecognised languages. They should publicly raise the question of whether these languages can be considered Indigenous, and put pressure on China to create the conditions where its citizens can choose whether they want to identify as Indigenous.

The United Nations, including bodies such as the Permanent Forum on Indigenous Issues, should play a role in this process. The United Nations Declaration on the Rights of Indigenous People clearly states, in Article 9, that 'Indigenous peoples and individuals have the right to belong to an indigenous community or nation, in 


\section{MELBOURNE ASIAREVIEW}

accordance with the traditions and customs of the community or nation concerned.' During the Decade of Indigenous Languages, the UN needs to provide a forum for critical examination of how member states deny this right. Since the right to identify as Indigenous is key to securing the other rights outlined in the Declaration, this needs to be a core focus.

It will be up to individual member states and civil society organisations to place pressure on China to recognise the right of its citizens to identify as Indigenous. An important opportunity for this will be Universal Periodic Review, wherein UN member states have their human rights records regularly assessed. China's next review is set for November 2023. In the 2018 Universal Periodic Review, civil society organisations and member states pressured China regarding the denial of human rights to speakers of recognised minzu languages, such as Tibetan. In 2023, attention should be placed on a much more fundamental issue: China's denial of indigeneity, and the isolation of its citizens from global civil society regarding Indigenous languages. In short, China should be pressured to live up to the motto of the International Decade for Indigenous Languages: 'nothing for us without us'.

Main image: Monks in front of the chanting hall in Lower Sengeshong Monastery, in the Tibetan region of Amdo. Most of the monks in this monastery are Tibetans who speak the Ngandehua language. Image taken by the author February, 2014. 